УДК: 61.616-092.18

BIOCHEMICAL COMPOSITION OF MEMBRANE PHOSPHOLIPIDS AND RESPIRATORY ACTIVITY OF MITOCHONDRIA OF HEPATOCYTES UNDER LONG EXPOSURE OF SODIUM FLUORIDE ON THE ORGANISM OF RATS

\title{
БИОХИМИЧЕСКИЙ СОСТАВ ФОСФОЛИПИДОВ МЕМБРАН И ДЫХАТЕЛЬНОЙ АКТИВНОСТИ МИТОХОНДРИЙ ГЕПАТОЦИТОВ ПРИ ДЛИТЕЛЬНОМ ВОЗДЕЙСТВИИ ФТОРИДА НАТРИЯ НА ОРГАНИЗМ КРЫС
}

Bagmut I.Yu./Багмут И.Ю. d.med.n, prof./ д.мед.н, проф. Koleshyk I.L./Колесник И.Л. k.med.n, as. prof/к.мед.н., доų. Ivanov A.S./Иванов A.C. graduate student/ acnupaнm ORCID: 0000-0002-9288-9892

\begin{abstract}
Fluorine chemical compounds are quite common and occur in the form of calcium, sodium, iron, aluminum and others fluoride. In turn, fluorine is highly active and is a non-metallic element that does not lend itself to biological decomposition and is contained mainly in groundwater, the prolonged use of which leads to the development of fluorosis. The study was carried out on mature rats, male Wistar line, weighing from 180 to $220 \mathrm{~g}$. All individuals received oral priming using a probe with an aqueous solution of sodium fluoride daily for 60 days at doses of 1/10, 1/100 and 1/1000 DL50, which respectively corresponded to $20 \mathrm{mg} / \mathrm{kg}, 2 \mathrm{mg} / \mathrm{kg}$ and 0.2 $\mathrm{mg} / \mathrm{kg}$ of body weight (median lethal dose for rats was $200 \mathrm{mg} / \mathrm{kg}$ orally). The control group received drinking water, the study was carried out on days 10, 20, 30, 50 and 60, each group included 10 animals. The study of the phospholipid composition of hepatocytes was carried out using the release of lipids with a mixture of chloroform-methanol at a concentration of 1: 2, followed by evaporation in a stream of dry nitrogen. Separation of individual phospholipids. To assess the respiratory activity of mitochondria, subcellular fractions were obtained using the differentiated centrifugation technique. It has been established that the respiratory activity of mitochondria is able to change significantly under the influence of chemical agents. The efficiency of the mitochondria depends on the coordination of the enzymes NADH-coenzyme $Q$ oxidoreductase and succinate-coenzyme Q-oxidoreductase, it is due to them that the processes of oxidative phosphorylation and the formation of macroenergetic bonds are provided. The above enzymes were exposed to specific substrates and inhibitors, they are the I and II complexes of the respiratory chain of the inner mitochondrial membrane of the hepatocyte. In the case of using sodium fluoride at a dose of 1/100 DL50 per 30 bitches, an increase in easily oxidized and difficultly oxidized phospholipid fractions is determined. On the 60th day of using this dose, the opposite dynamics is observed, the indicators of easily oxidized fractions decrease with increased indicators of difficult oxidized phospholipids. Analysis of the respiratory activity of mitochondria of hepatocytes indicates a violation of the separation of the processes of oxidation and phosphorylation on substrates of the II complex of the mitochondrial respiratory chain on the 60th day of sodium fluoride action both when using a dose of $1 / 10$ and a dose of 1/100 DL50, as a result of which an energy imbalance develops.
\end{abstract}

Key words: sodium fluoride, hepatocytes, phospholipids, mitochondria, respiratory activity.

Fluorine chemical compounds are quite common and occur in the form of calcium, sodium, iron, aluminum and others fluoride. In turn, fluorine has a high activity and is a non-metallic element that does not lend itself to biological degradation and is contained mainly in groundwater, long-term use of which leads to 
the development of fluorosis [1].

The study of sodium fluoride showed its effect on the structure of hepatocyte membranes, as well as intracellular components, leads to stimulation of lipid peroxidation, disruption of tissue respiration and the formation of toxic metabolic products [2-5]. Subsequently, sodium fluoride and the end products of its metabolism are excreted by the kidneys. The relevance of studying fluoride on the body is due to its insufficiently studied biological activity. Since this substance is used as a wood preservative, in the composition of pesticides and various substances for gluing surfaces. Some studies have shown a decrease in the amount of protein in the liver and serum of rats exposed to sodium fluoride [5-7].

Excessive activity of lipid peroxidation leads to destabilization of the lipid bishar of the hepatocyte against the background of a reduced antioxidant reserve. Toxic products resulting from the metabolism of sodium fluoride by liver cells affect the structure and function of organelles, primarily the respiratory activity of mitochondria [8].

\section{Materials and methods.}

The study was carried out on sexually mature male Wistar rats, weighing from 180 to $220 \mathrm{~g}$. DL50, which respectively corresponded to $20 \mathrm{mg} / \mathrm{kg}, 2 \mathrm{mg} / \mathrm{kg}$ and $0.2 \mathrm{mg} / \mathrm{kg}$ of body weight (the median lethal dose for rats was $200 \mathrm{mg} / \mathrm{kg}$ orally). The control animals received the appropriate amount of drinking water. The study of the indicators was carried out on days 10,20,30,50 and 60 after the beginning of the experimental part, each group included 10 animals. The slaughter was carried out by decapitation with a guillotine knife under anesthesia with sodium thiopental solution at a dose of $50 \mathrm{mg} / \mathrm{kg}$ body weight.

The study of the phospholipid composition of hepatocytes was carried out using the release of lipids with a mixture of chloroform-methanol at a concentration of $1: 2$, followed by evaporation in a stream of dry nitrogen. Separation of individual phospholipids. The separation of phospholipids into fractions was carried out using the technique of microlayer chromatography in a solvent system that included hexane, diethyl ether, and acetic acid in a ratio of 73: 25: 2 [9]. Phospholipids were identified using standard solutions and specific reactions. The quantitative content of total and individual phospholipids in the lipid extract was estimated by the amount of inorganic phosphorus, which was determined using the mibdenic reagent [10]. The ratio of phospholipid fractions was calculated as a percentage of phospholipid phospholipids of each fraction to phosphorus of lipid communities, taken as $100 \%$.

To assess the respiratory activity of mitochondria, subcellular fractions were obtained using the differentiated centrifugation technique. Isolation of the microsomal fraction was carried out by centrifuging the supernatant for an hour at $18000 \mathrm{~g}$, the resulting precipitate was washed and suspended in the isolation medium (the protein content in the microsome suspension was $15-20 \mathrm{mg} / \mathrm{ml}$ ). using the polarographic method, the respiratory activity of hepatocyte mitochondria was assessed. The functional state of complexes I and II of the respiratory chain was determined in the presence of specific substrates and inhibitors using the parameters: 1) the state of $V_{4}$ - under the condition of a high content of substrates of complex I in the incubation medium - $5 \mathrm{mM}$ glutamate, $5 \mathrm{mM}$ malate or substrate II of complex - 
succinatua in the absence of ADP; 2) V3 state - similar conditions as for $\mathrm{V}_{4}$, but in the presence of $200 \mu \mathrm{M}$ ADP (in this case, the respiratory chain is the limiting factor of the reaction rate); 3) Vd state - similar conditions as for the case of $\mathrm{V}_{4}$, but in the presence of an oxidation and phosphorylation separator of $30 \mu \mathrm{M}$ 2,4-dinitrophenol. Mitochondria were isolated by differential centrifugation: liver tissue was homogenized in a medium with $250 \mathrm{mM}$ sucrose, $3 \mathrm{mM}$ Tris- $\mathrm{HCl}$ buffer with 0.5 $\mathrm{mM}$ EDTA ( $\mathrm{pH} 7.3$ ), the homogenate was centrifuged at $700 \mathrm{~g}$, the resulting supernatant was centrifuged in a medium with $250 \mathrm{mM}$ sucrose, $3 \mathrm{mM}$ Tris- $\mathrm{HCl}$ buffer (pH 7.3) at $7000 \mathrm{~g}$.

Statistical calculations were performed using the Statistica 10 software.

\section{Research results.}

On the 30th day of oral administration of sodium fluoride at a dose of $1 / 10$ DL50 in relation to easily oxidizable phospholipid fractions, a 36\% decrease (p $<0.001$ ) was observed in comparison with the control group in the level of phosphatidylethanolamine (PEA), at the same time, a 22\% decrease $(\mathrm{p}=0.059)$ of the content of phosphatidylinositol (PI), the level of phosphatidylserine (PS) increased by $7 \%(\mathrm{p}=0.762)$. With regard to difficultly oxidized fractions of phospholipids, an increase of $35 \%(\mathrm{p}<0.001)$ in the level of phosphatidylcholine (PC) and lysophosphatidylcholine (LPC) by $92 \%(\mathrm{p}<0.001)$ was observed against the background of a reduced amount of sphingomyelin (SM) by $41 \%(\mathrm{p}<0.001)$.

It has been established that the respiratory activity of mitochondria is able to change significantly under the influence of chemical agents. The efficiency of the mitochondria depends on the coordination of the enzymes NADH-coenzyme Qoxidoreductase and succinate-coenzyme Q-oxidoreductase, it is due to them that the processes of oxidative phosphorylation and the formation of macroenergetic bonds are provided. The above enzymes were exposed to specific substrates and inhibitors, they are the I and II complexes of the respiratory chain of the inner mitochondrial membrane of the hepatocyte.

Oral administration of sodium fluoride led to the fact that on the 30th day of the experiment at a dose of 1/10 DL50, an increase in the respiration rate of mitochondria of hepatocytes in states $\mathrm{V}_{3}$ and $\mathrm{V}_{4}$ to the substrates NADH-coenzyme Qoxidoreductase was observed by 46 and $26 \%(\mathrm{p}<0.001)$, respectively, in comparison with the control group. The effect of sodium fluoride led to a decrease in the respiratory activity of mitochondria in the $\mathrm{V}_{3}$ and $\mathrm{V}_{4}$ states on the substrates of succinate-coenzyme Q-oxidoreductase by 16 and 36\% ( $\mathrm{p} \leq 0.002)$, respectively. In the presence of 2,4-dinitrophenol, the dynamics of changes in relation to the control group of animals was recorded only for the state $\mathrm{V}_{\mathrm{d}}$ on succinate, the decrease reached 25\% $(\mathrm{p}<0.001)$.

On day 60, the effect of sodium fluoride at a dose of 1/10 DL50 led to a decrease in the respiratory activity of mitochondria of hepatocytes in states $\mathrm{V}_{3}$ and $\mathrm{V}_{4}$ on the substrate NADH-coenzyme Q-oxidoreductase by 39 and $25 \%(\mathrm{p}<0.001)$, respectively, as well as on the substrates succinate-coenzyme Q -oxidoreductase by 38 and $53 \%(\mathrm{p}<0.001)$. For the state $\mathrm{Vd}$ on succinate, the tendency to decrease by $45 \%$ persisted.

On the 60th day of the action of sodium fluoride at a dose of 1/10 DL50 
observed a decrease in the hepatocytes of PEA and PI rats by 60 and $57 \%(\mathrm{p}<0.001)$. The FS indicator decreased by $19 \%(\mathrm{p}=0.059)$. Along with this, the level of LF increased by $122 \%$ and $\mathrm{FH}$ by $52 \%(\mathrm{p}<0.001)$. The SM content under the action of sodium fluoride at a dose of $1 / 10$ DL50 on day 60 decreased by $62 \%$ in comparison with the control group.

Oral administration of sodium fluoride at a dose of 1/100 DL50 led to a different change in the phospholipid composition of hepatocytes. On the 30th day, among the easily oxidized fractions, only the PI increased by $42 \%(p=0.004)$, while the PEA index increased by $21 \%(\mathrm{p}=0.104)$. The PS content did not change during the entire period of sodium fluoride use. For difficultly oxidized phospholipid fractions, on the 30th day of the experiment, the use of sodium fluoride at a dose of 1/100 DL50 only showed an increase in LPC by $43 \%(\mathrm{p}<0.001)$. The indicators of SM and PC did not change in comparison with the control group.

On the 60th day of the action of sodium fluoride at a dose of 1/100 DL50, the PEA and PI values decreased by $40-48 \%(\mathrm{p}<0.001)$. The FS level did not change and corresponded to the control group. Sodium fluoride at a dose of 1/100 DL50 led to an increase in the amount of PC and LPC on day 60 by 26 and $47 \%(\mathrm{p}<0.001)$ against the background of a decrease in SM by an average of $40 \%(\mathrm{p}<0.001)$.

On the 30th day of the action of sodium fluoride at a dose of 1/100 DL50, an increase in the rate of oxygen consumption by mitochondria of rat hepatocytes in states V3 and V4 was established, both on substrates of NADH-coenzyme Qoxidoreductase by 29 and $36 \%(\mathrm{p}<0.001)$, and on substrates of succinate -coenzyme Q-oxidoreductase by 27 and $32 \%(\mathrm{p}<0.001)$. For the $\mathrm{Vd}$ state on the substrates of both enzymes, practically no changes were revealed during this observation period. On day 60, in 1/100 DL50, sodium fluoride led to an average increase of $23-34 \%$ $(p \leq 0.001)$ in the respiratory activity of mitochondria in states V3 and V4 on substrates of NADH-coenzyme Q-oxidoreductase against the background of a decrease on average by $18-33 \%(\mathrm{p} \leq 0.001)$ on succinate-coenzyme Q-oxidoreductase substrates. The addition of 2,4-dinitrophenol resulted in a $23 \%(\mathrm{p}<0.001)$ decrease in the respiration rate of rat hepatocyte mitochondria in the presence of succinatecoenzyme Q-oxidoreductase substrates. The respiration rate of rat hepatocyte mitochondria in the $\mathrm{Vd}$ state on glutamate and malate under the action of sodium fluoride at a dose of 1/100 DL50 did not show significant changes and was equal to the control group.

The results obtained indicate a decrease in the readily oxidized phospholipid fractions of rat hepatocytes, primarily PEA and PI, against the background of an increase in difficultly oxidized PC, LPC upon prolonged administration of sodium fluoride at a dose of 1/10 DL50. In the case of using sodium fluoride at a dose of $1 / 100$ DL50 per 30 bitches, an increase in easily oxidized (PEA, PI, PS) and difficultly oxidized (LPC) phospholipid fractions is determined. On the 60th day of using this dose, the opposite dynamics is observed, the indicators of easily oxidized fractions (PEA, PI) decrease with increased indicators of difficultly oxidized (PC, LPC) phospholipids. Such changes may be a consequence of the established increase in free radical processes and lipid peroxidation during prolonged exposure to sodium fluoride. 
A significant increase in LPC with prolonged use of sodium fluoride has a pronounced cytolytic effect. SM is resistant to peroxidation by the phospholipid fraction, however, the use of a dose of 1/10 DL50 of sodium fluoride led to its gradual decrease in the hepatocyte membrane, which indicates in favor of the chronization of the processes of free radical oxidation and lipid peroxidation.

As for the respiratory activity of mitochondria, the results obtained, the results obtained speak in favor of its violation when using sodium fluoride. On the 30th day of the experiment, the dose of sodium fluoride 1/10 DL50 led to a decrease in the activity of succinate-coenzyme Q-oxidoreductase, and on the 60th day the index of $\mathrm{NADH}$-coenzyme Q-oxidoreductase and succinate-coenzyme Q-oxidoreductase decreased. Exposure to sodium fluoride at a dose of 1/100 DL50 leads to disruption of the respiratory activity of mitochondria on the 60th day, as evidenced by a decrease in the activity of succinate-coenzyme Q-oxidoreductase. The revealed changes are explained by the initiation of free radical reactions by sodium fluoride and lipid peroxidation, the products of which are factors of damage to the membrane, including the mitochondrial membrane, where the respiratory chain is located. An increase in the activity of mitochondrial NADH-coenzyme Q-oxidoreductase under the action of sodium fluoride at a dose of 1/100 DL50 is observed, which can be interpreted as a protective reaction.

\section{Conclusions.}

Calculation of the ratio of the ratio of the sum of easily oxidizable phospholipid fractions, which include - PS, PEA, PI to the sum of difficultly oxidized phospholipid fractions - CM, PC, LPH under the action of sodium fluoride at a dose of 1/10 DL50 indicates its decrease on day 30 in 1, 4 and 60 days 2.3 times, which reflects the depletion of the adaptive potential of liver hepatocytes. The use of sodium fluoride at a dose of 1/100 DL50 led to an increase in the coefficient by 1.2 times on the 30th day and a decrease by 1.6 times on the 60th day, which testifies to the tension of the adaptive potential with its subsequent breakdown. Analysis of the respiratory activity of mitochondria of hepatocytes indicates a violation of the separation of the processes of oxidation and phosphorylation on substrates of the II complex of the mitochondrial respiratory chain on the 60th day of sodium fluoride action both when using a dose of $1 / 10$ and a dose of 1/100 DL50, as a result of which an energy imbalance develops.

\section{Literature.}

1. Bagmut I., Kolisnyk I., Titkova A., Gramatiuk S., Gozhenko A. The state of dopamine, serotonin, adrenal and glucocorticoid receptors in chronic fluoride intoxication. Archives of the Balkan Medical Union. Vol. 54, no. 2, pp. 253-259 June $2019 \mathrm{https} / /$ doi.org/10.31688/ABMU.2019.54.2.05

2. Tabuchi Y, Yunoki T, Hoshi N, et al. Genes and gene networks involved in sodium fluoride-elicited cell death accompanying endoplasmic reticulum stress in oral epithelial cells. Int J Mol Sci. 2014;15 (5):8959-8978. 13.

3. Bagmut I, Kolisnyk I, Titkova A. The pathochemical mechanisms of action of sodium flouride on the body. LAP Lambert Academic Publishing. 2017: 43 p.

4. Meng H, Zhang T, Liu W, et al. Sodium fluoride induces apoptosis through the downregulation of hypoxia-inducible in primary cultured rat chondrocytes. Int $J$ 
Molofactor-1 Med. 2014;33(2):351-358.

5. Al-Okaily, B. N. Effect of Pomegranate Seed Oil against HepatotoxicityInduced by Sodium Fluoride in Adult Female Rats (Part II). The Iraqi Journal of Veterinary Medicine (ISSN-P: 1609-5693 ISSN-E: 2410-7409), 2019. 43(1), 102-112.

6. Jha, A.; SHAH, K. and VERMA, R. Effects of sodium fluoride on DNA, RNA and protein contents in liver of mice and its amelioration by Camellia Sinensis. Acta Poloniae Pharmaceutica-Drug Research. 2012. 69(3), 551555.

7. Ali, E.H. and Al-Okaily,B.N. The protective role of pomegranate seed oil (Pometone) on serum protein in sodium fluoride treated female rats.(Part I). IJVM. 2016. 39 (2):61-68.

8. Kolisnyk, I., Bagmut, I., Titkova, A., Rezunenko, Y., Filipchenko, S. The damage of membranes structure of hepatocytes in rats during fluoride intoxication. The Medical and Ecological Problems. 2017. 21(5-6), 65-66. Retrieved from https://ecomed-journal.org/index.php/journal/article/view/107

9. Кейтс М. Техника липидологии / М. Кейтс. - М. : Мир, 1975. - 322 с.

10. Brockhuse R. M. Phospholipids structure of erythrocytes and hepatocytes / R.M. Brockhuse // Clin. Biochem. - 1974. - Vol. 14, № 3. - P. 157-158.

Аннотация. Химические соединения фтора довольно распространены и встречаются в виде фторида кальция, натрия, железа, алюминии и других. В свою очередь фтор имеет высокую активность и представляет собой неметаллический элемент, который не поддается биологическому разложению и содержится преимущественно в грунтовой воде, длительное употребление которой приводит к развитию флюороза. Исследование было проведено на половозрельх крысах, самцах линии Wistar, весом от 180 до 220 г. Все особи получали пероральную затравку при помощи зонда водным раствором фторида натрия ежедневно в течение 60 суток в дозах 1/10, 1/100 и 1/1000 ДЛ50, что соответственно отвечало 20 мг/кг, 2 мг/кг и 0,2 мг/кг массы тела (среднелетальная доза для крыс составила 200 мг/кг пероорального введения). Контрольная группа получала питьевую воду, исследование проводили на 10, 20, 30, 50 и 60 сутки,каждая группа включала 10 животных. Изучение фосфолипидного состава гепатоцитов провели при помощи выделения липидов смесью хлороформ-метанол в кониентрачии 1:2 с последующии испарением в струе сухого азота. Разделение индивидуальных фосфолипидов. Для оиенки дыхательной активности митохондрий получили субклеточные фракции при помощи методики дифференцированного центрифугирования. Установлено, что дыхательная активность митохондрий способна значительно изменятся под действием химических агентов. Эффективность работь митохондрий зависит от слаженности работы ферментов НАДН-коэнзимQоксидоредуктазы и сукиинат-коэнзимQ-оксидоредуктазы, именно за счет них обеспечиваются прочессы окислительного фосфорилирования и образование макроэнергетических связей. На вышеуказанные ферменты проводилось воздействие специифическими субстратами и ингибиторами, именно они являются I и II комплексами дыхательной цепочки внутренней митохондриальной мембраны гепатоцита. В случае использования фторида натрия в дозе 1/100 ДЛ50 на 30 суки определяется повышение легко окисляемых, так и сложно окисляемых фосфолипидных фракций. На 60 сутки использования этой дозы наблюдается противоположная динамика, снижаются показатели легко окисляемых фракций при повышенных показателях сложно окисляемых фосфолипидов. Анализ дыхательной активности митохондрий гепатоцитов свидетельствует о нарушении разъединения проиессов окисления и фосфорилирования на субстратах II комплекса митохондриальной дыхательной иепи на 60 сутки действия фторида натрия как при 
использовании дозы 1/10 так и дозы 1/100 ДЛ50, вследствие чего развивается энергетический дисбаланс.

Ключевые слова: фторид натрия, гепаточиты, фосфолипиды, митохондрии, дыхательная активность.

Статья отправлена: 29.11.2020 г.

(C) Багмут И.Ю. 